\title{
A QUALITATIVE EXPLORATION OF STUDENTS' EXPERIENCES WITH ACQUIRING CULTURE DURING FOREIGN LANGUAGE INSTRUCTION
}

\author{
Halis Gözpınar \\ Giresun University, Giresun, Turkey \\ halisgozpinar@gmail.com
}

\begin{abstract}
Language teachers ought to give their students a sound grounding in what is known as the five C's-communication, communities, cultures, connections, and comparisons - in addition to the classic four basic language skills. This study examines how first-year Turkish students currently enrolled in a culture course at Giresun University view culture-focused courses, and how much cultural training they had received (if any) in high school prior to entering university. This study is qualitative in nature, and provides information by using multiple sources of data. The fact of the matter is that their high school teachers focused more on grammar and avoided culture due to the constraints of both time and of an exam-oriented education system. Regarding the benefits, the course has pushed them to examine the relationship between language and culture, offered a reason to study the target language, and made the learning process real. It takes patience and effort in order to convince youth of the necessity of languages, as well as to make them better aware of, and to dispel their prejudices towards other cultures. The study also provides recommended practices that can encourage educators to implement during foreign language instruction.
\end{abstract}

Keywords: higher education; language teachers; intercultural awareness; foreign language instruction; language skills.

\section{Introduction}

Foreign language students who view language as only being comprised of strings of words, and who almost completely overlook the aspect of culture are likely to misinterpret those from other ethnic and cultural backgrounds upon contact. In his paper "The Inevitability of Teaching and Learning Culture in a Foreign Language Course", Valdes (1990) notes that even a simple seven-word sentence such as "I went to the library last night" undeniably carries a wealth of hidden meaning even if no such fallout intended by the speaker/writer. EFL classes ought not to teach language separate from culture, given that even the most basic of sentences can be laced with culture reference. Language scholars such as Brown, 2000; Brooks, 1969; Damen, 1987; Byram, 1997; Kramsch, 1993 back this by suggesting that is impossible to separate language from culture, noting that one without the other is insignificant. As Hofstede \& Hofstede (2005) point out, "studying a language without being exposed to its culture is like practising swimming without water" (p. 11).

Countless cultural training-centred studies take a look at the roles and viewpoints of foreign language teachers, the reasons behind the complexity of teaching culture, and curriculum expectations (Davis and Markham, 1991; Sercu, 1998; Sercu, 2005; Byram, 1991; Byram \& Fleming, 1998; Byram, Gribkova \& Starkey, 2002; Crawford-Lange \& Lange, 1984; Stern, 1983; Byrd et al., 2011; Kahraman 2016; Matsumoto, 2009; Byram, Morgan, \& colleagues, 1994; Thanasoulas, 2001). According to Kitao (2000), studying the target culture is useful in that it helps learners better understand the language, to communicate with the people of that culture, as well as to better grasp their own culture. Alptekin (2002) emphasises that "learning a foreign language becomes a kind of enculturation" (p. 58). In the words of Stainer (1971), in saying that "when pace lags, when the eyes drop, when the heat comes, the smart teacher will have the cultural unit" (p. 63), makes one notice that studying culture will encourage and motivate students when it comes to studying the target language.

Tomalin (2008) adds culture as a fifth skill to the other four basic language skills of listening, speaking, reading, and writing. This fifth skill, in fact, refers to an "attitudinal change" of sorts. Kramsch (1993), however, disagrees with Tomalin's approach, and argues that the influence of culture in the language classroom is placed on a much higher pedestal, and that real learning is not possible unless language as a cultural tool is first learned.

Language teachers ought to give their students a sound grounding in what is known as the five C'scommunication, communities, cultures, connections, and comparisons - in addition to the classic four basic language skills (National Standards in Foreign Language Education Project, 2006). As one may observe, the final three C's in particular pertain to culture. Culture, in and of itself, is an expansive concept. Textbook authors, publishers, and teachers thus ought to work together in order to weave culture into the foreign language learning curriculum in a manner that appeals to a wider audience. It should not be forgotten that teachers hold a key role in ensuring that their students gain a non-judgmental and inquisitive attitude towards other cultures. Edgerton (1971) and Morain (1970) stress that an ideal language learner should be openminded about the cultural elements of others. Seelye (1984) also emphasises the general educative value of cultural learning, defends culture's role in the curriculum, and portrays the teacher as being the facilitator. 


\section{Culture teaching in ELT}

Towards the end of the 1970s, the teaching of culture within language training had reached a state of international importance, and thus had begun to be introduced into the classroom. A number of studies published throughout the 1970s cite that culture-oriented courses motivate students to become more interested in the language(s) they are studying (Keller \& Ferguson, 1976; Steiner, 1971; Klayman, 1976; Leward, 1974; Bourque \& Chehy, 1976). Many studies and debates on how culture ought to be taught as well as which topics within culture ought to be included (Kitao, 2000) had emerged throughout the 1980s and 1990 (Minami \& Ovando, 2004; Nelson 1995; Harrison 1990; Rivers 1981; Hammerly 1982, Higgs, 1984; Omaggio, 1986). From the 1990s and onwards, the contributions of Byram and Kramsch, in particular, stand out when it comes to the field of culture-centric language teaching (Kramsch, 1998; Kramsch, 2001; Byram, 1994; Byram, 1989; Byram, 1994). The cultural knowledge gained in the language classroom, as well as learner's level of perception, positively impacts their points of view (Cortazzi \& Jin, 1999; Klippel, 1994; Pulverness, 1999; Peck, 1998).

In the $21^{\text {st }}$ century, researchers interest in teaching the target culture together with the target language has only peaked (Bennett, 1997; Cakir, 2006; Ho, 2009; Schuetze, 2008; Fox \& Diaz-Greenberg, 2006; Drewelow, 2013; Barnes-Karol \& Broner, 2010; Izadpanah, 2011; Jiang, 2012; Karabinar \& Guler, 2012; Chlopek, 2008 and Sercu, Gracia, and Prieto, 2004). Tsou (2005), Yeşil, and Demiröz (2017) each put forth that teaching the target culture has a positive motivational impact on students' proficiency levels in English. Cheung (2001) shows us that it also motivates teachers as well. The results of a study by Duff (2001) furthermore suggest that students need to be versed in popular culture, be able to critically discuss various social topics, and be able to effectively communicate in order to be deemed realistically successful in a foreign language. Choudhury (2014) observed that studying English without proper awareness of its culture will make it very difficult to correspond in real life situations. Learning cultural aspects of the language helps students improve their communicative skills and enrich their understandings (Gorjian \& Aghvami, 2017, p.77). Hejazi et al. (2015) concluded that being prejudiced against different cultures may "limit the flexibility of the mind in the process of comprehending L2 passages". Devrim and Bayyurt (2010) have revealed that students want to see cultural elements from both the target language culture as well as from the local culture in foreign language classrooms and materials. This automatically leads to a healthy class environment, and will improve the student's likelihood of success (Hol \& Erarslan, 2015). Dweik \& Al-Sayyed (2015) and Jabeen \& Shah (2012) back this, but from the angle of Islamic societies, whereby they found that students want to see elements pertaining to Islamic culture in their language-learning materials. Chlopek (2008) suggests various activities in order to make students more cross-culturally adept. Baker (2012) also goes into detail about how to include cross-cultural awareness in the foreign language classroom. Genç \& Bada (2005) note that language students struggle to communicate with native speakers because of a lack of cultural context. Rafieyan et al. (2013) invite course book designers to explore new methods and materials to teach culture.

One study by Sercu (2005) suggests that teachers in Belgium, Bulgaria, Greece, Mexico, Poland, Spain and Sweden are open-minded about teaching intercultural communicative competence (ICC) in their classrooms. The study by Demircioğlu \& Çakır (2015) also suggests that English language teachers from Turkey, the USA, the UK, New Zealand and Spain have a positive attitude towards the teaching of culture. Tuna \& Razı (2016); Önalan (2005); Gonen \& Saglam (2012) further revealed that teachers addressed the need to incorporate cultural information in the foreign language classroom. Moreover, a number of teachers are of the opinion that culture is important enough that it should be taught as a separate course (Saluveer, 2004). Many universities in the world have developed courses aimed at teaching the target culture as part of their foreign language programmes (Han, 2016).

Students must be taught with the right methodology, a broad spectrum of materials, sufficient information, and reliable equipment. One should keep in mind that teachers play a pivotal role when it comes to effectively using such materials (Adaskou et al., 1990). A study by Gözpınar (2014) reveals that high school teachers in Turkey lack the competency in order to teach cultural elements. Atay et al. (2009); Demircioğlu \& Çakır (2015); Kahraman (2016) feel that teacher training in Turkey needs to be reassessed and universities should include courses to improve future teachers' intercultural awareness. According to Eoyang (2003), most foreign language textbooks are not culturally appropriate, and thus fail to help students to meaningfully communicate in English. Stapleton (2000) also disapproves of the almost complete absence of culture in foreign language textbooks. Turkan and Celik (2007) offer specific ways on how to integrate culture into their classrooms and supplement their textbooks with cultural elements.

Many teachers consciously avoid teaching culture altogether. According to Krashen (1982), cultureunlike language — cannot be acquired within the four walls of the classroom, but instead needs to be learned 
within a more natural environment. Damen (1987) agrees with Krashen, points out that while the basic rules of a culture can be taught in the classroom; those rules still cannot represent that culture in terms of its dynamics. According to Stern (1992), the difficulty of according an inappropriate place to culture in a predominantly language-oriented approach and handling substantive subject-matter in a mainly skill-oriented programme are important problems within cultural studies.

Alptekin (2002), in citing the English language as being a global lingua franca, suggests that English thus should not be taught within the context of American and British culture alone. Fishman (1982) describes English and its worldwide appeal as being "without love, without sighs, without tears and almost without effect of any kind" (p. 20). Hamp-Lyons (1983) argues that in such a case, the study of culture is out of place. A study by Smith (1976) also contends that the teaching of culture in the classroom is of little value given the international status of English. Smith feels that English is a communication tool that now belongs to no one culture in particular.

EFL teachers often find themselves entangled in the middle of debates surrounding linguistic and cultural imperialism, and therefore steers the teacher away from the topic of culture outright. Teaching culture is also viewed by many as being a time-consuming process and menacing (Galloway, 1985). This is due in large part to teachers' lacking sufficient knowledge about culture, as well as due to their hesitation to bring culture into the classroom (Hadley, 1993). According to Alsamani (2014), if the values of the target culture are contrary to own cultures, teachers may not bring into the classroom. Ahmad \& Shah (2014) also mentioned that students and the parents did not like the content of the English textbooks in Saudi and complained about bringing culturally inappropriate materials into the classroom in some Saudi language institutions.

\section{The study}

Culture-themed courses with different names can also be found in many English Language/Literature and TEFL programmes throughout most Turkish universities. This study examines how first-year Turkish students currently enrolled in a culture course offered by the Department of English Language and Literature at Giresun University view culture-themed courses, and how they feel that the study of culture has shaped them. The study also takes a look at how much cultural training they had received (if any) in high school prior to entering university. The following research questions guiding the study include:

1. How did the teaching and learning of culture contribute to the students' development?

2. What are students' experiences with the teaching and learning of culture in Turkish high schools?

3. What are the recommendations for how culture ought to be taught and learnt in foreign language instruction?

\section{Participants:}

These students had earned the right to study in this department upon successfully passing an English language proficiency following graduation from high school. The sample group consisted of 52 (fifty-two) students between the ages of 17 and 26 (forty females, twelve males).

The participants were classed as being upper-intermediate (B2) speakers of English. In addition to Turkish and English, many students had knowledge of a number of other languages as well, including Kurmanji Kurdish, Greek, Zaza, German, Russian, Korean, French, Arabic, Laz, Bulgarian, Georgian, Azerbaijani, and Spanish.

Only three students had reported having travelled abroad. One student had reported spending seven days in Europe as part of an Erasmus+ programme offered through their high school.

\section{Main Content of the Course}

The course enables participants to gain a better understanding of the nature of cultural studies as a discipline. It aims to improve their own English language by placing a special emphasis on English, British, American, Anglophone Culture and Society and using a variety of teaching practices and methodologies. In the following academic years at the university, they will have methodology classes on how, in what ways, at what level and at what language level culture instruction will be done. 


\section{Role of the Researcher}

The researcher is one of the teachers of the course. He held various debates, activities, presentations, resources, and talks by guest speakers. The researcher has about 20 years of experience as a teacher of English as a Foreign Language (EFL) in state schools throughout Turkey, as a coordinator in various "LifeLong Learning Erasmus+" and "Associated Schools" programmes, as well as a teacher of Turkish as a Foreign Language (TFL) abroad.

\section{Tools}

This study is qualitative in nature, and provides information by using multiple sources of data. The data collection instruments consisted of five tools:

a) a profile form; b) open-ended questions; c) interviews; d) focus group discussions; e) essay writing.

The researcher had noticed that his first-year students were severely lacking in terms of even a basic knowledge about the target culture in question. Data were collected at the beginning of the first half of the culture course (autumn semester) in order to learn about students' prior experiences with cultural training. The students then had completed a total of 64 hours of cultural training over a period of two semesters. Upon completion of the course, during the second or spring semester, the researcher had recollected more data in order to reassess their experiences.

Data analysis: The researcher scanned, categorised, and coded the data collected through multiple sources in order to ensure validity and accuracy and then reorganised, grouped according to themes, and presented. What emerged the end of the analysis were two (students' experiences with acquiring culturebased) themes:

1. Contributions of the cultural trainings

2. Students experiences with studying culture in high school

Every student in the department had participated, and had helped the researcher fulfil the goals and intentions of the study. The data obtained from various tools were also presented in two tables (Appendixes $1 \&$ 2). This study gives priority to finding out what English Language and Literature students think about the role and benefits of cultural trainings in foreign language instruction. The outcome of this study is anticipated to contribute to the current academic literature.

\section{Findings}

\section{Contributions of the Cultural Trainings}

\section{Language Skills Development}

The findings indicate that the students understand better the role of language in the formation and survival of a culture; the impossibility of understanding a language without the comprehension of its culture. Their level of understanding at thus improved, and they had also begun to approach learning with a more critical eye, as one highlighted below:

"The idea that the concept of culture is acquired over time always sits in the back of your mind, and you approach the texts you read keeping with that in mind. I now feel myself more ready to dive into nitty-gritty of the target culture. I feel that I have gained the ability to better communicate and conceptualize."

First of all, the students believe that their ability to use the language in meaningful contexts and with the right vocabulary improves. Secondly, their participation in the course had also improved their reading skills in English. This class has beneficial effects on the students' language skills as one of the participants mentioned:

"I learned the rules of English grammar better while absorbing the culture. Learning English isn't just about memorising vocabulary, you instead should learn how to use English through meaningful contexts. Those classes make a huge contribution to your communication in a culturally appropriate way."

\section{Developing the Cultural Awareness Skills}

The data gathered in this survey show that the cultural studies course had positively shaped how students perceived culture. Students had mentioned about how the course had also offered them the chance to compare and contrast the target culture with their own culture. Furthermore, most had emphasised discovering, through the course, the commonalities that thread cultures together, as one of them highlighted: 
"It had helped me get past my prejudices as well as wrong dogma. I learned how to establish a sense of enlightenment. Other cultures now no longer come across to me as being strange or weird. Instead, other cultures merely are different from my own."

Due to the fact that a number of students hold rather nationalistic dispositions, they thus tend to shy away from learning either the language or culture. To the contrary, one student notes that students are able to discuss how foreign languages, in fact, have made them become fervent advocates of their own culture, and about how they want to share their passion with the rest of the world. According to her, such persons are also able to talk about their values and where those values come from effortlessly.

The feedback from one student, who claims that cultural studies training had aroused their interest in participating in international exchange programmes, had the following to say about the positive change that they had experienced:

"I have a higher level of self-confidence in participating international education programmes after these courses."

Our results on the contributions of the cultural studies course to the students' language skills and cultural competence are largely consistent with the findings of Genç and Bada (2005), who also explored students' opinions regarding the benefits of attending culture training.

The results of this study too are surprisingly similar to those from Bhawuk and Brislin (1992): "To be effective in another culture, people must be interested in other cultures, be sensitive enough to notice cultural differences, and then also be willing to modify their behaviour as an indication of respect for the people of other cultures" (p. 416).

\section{Students' experiences of teaching and learning of culture in High Schools}

The result of the data that was collected shows that the majority of students' felt that their high school English teachers paid little attention to the topic of culture. One of the participants in the study had noted that the textbooks they had used at most contained one or two sentences about the target culture, and that their teachers, more often than not, would skip over those sections due their own foreignness towards the subject, and would instead focus merely on cold linguistic rules.

One participant mentions that they were unable to form any sort of bridge between their own culture and what they remember learning in high school. Majority of the students think that curriculum, activities, and materials should be better planned and prepared. They reasoned why their teachers had to ignore culture teaching:

"I cannot say that my teacher was poor even if they failed to teach us anything about culture. The fact of the matter is that our teachers focus more on grammar and avoid culture due to the constraints of both time and of an exam-oriented education system."

One participant, in indicating that culture is both an abstract as well as a concrete subject; felt that the concrete side of culture needs to be brought into the foreground for those whose grasp of culture is limited.

Furthermore, the students think that teachers should encourage them to research what they are learning in greater depth. They remind that this encouragement will guide them in terms of teaching them how to access reliable information, as well as how to discern credible from non-credible resources.

The nature of teaching demands that teachers engage in continuing career-long professional development (Day, 1991). According to Lunenburg and Ornstein (2012), administrators also need to help all teachers reach their potential by learning new skills and developing their abilities to the fullest (p.503). One student, in claiming that universities ought to show more attentiveness towards this particular matter, talked about high school teachers being able to professionally develop themselves through various resources, conferences, and seminars. In furthering this point, another student had pointed out the following:

"It is absolutely important that teachers today be versed in new teaching methods, as well as be able to prepare materials. It is through our university's cultural studies course, as well as through the support of our instructor, that I became familiar with authentic cultural materials."

\section{Discussion}

\section{Powerful Strategies and Recommended Practices}

This paper represents the sum of extensive observation of foreign language instruction from a range of educational environments. What can be concluded from these observations is that the expectations of the current curriculum, teachers' overall lack of interest in culture, gaps in how the subject of culture is dealt with and taught, as well as students' driving a wedge between their own culture and the target culture are just some of a large number of reasons behind why teachers put culture onto the back burner, so to speak. All of 
these reasons need to be assessed by both the student and the teacher in order for cultural studies to be successful. This section will highlight a number of sound approaches in order to properly teach culture.

\section{Choosing Appropriate Materials}

Students first come into contact with the culture of the language they are studying the moment their teachers bring cultural materials to the classroom. One of the most beautiful and valuable aspects of foreign language education is working with meaningful reading materials that contain different cultural perspectives. McKay (2002) suggests that teachers pay attention to the needs of their students. The materials that teachers use need to be chosen carefully and cleverly, appeal to students of all backgrounds, and not set the teacher behind in the midst of their curriculum. At the time, teachers also need to find out what their students need, and to prioritise those needs in terms of importance. Çakır (2015) suggests that using instructional materials will motivate learners and offer an interactive foreign language teaching atmosphere. Students are likely to lose interest should teachers' materials not be in sync with their personal pedagogical styles. A drop in motivation only spells a drop in learning, or as one academic puts it, [students] will "switch off and retreat into their inner world to defend their own integrity" (Prodromou 1988, p. 80).

Teachers should also choose their teaching method according to the overall mood of the class. They should prepare and supply their students with various fun activities - some of which, in small doses, can be given through students' first language, however at the same time should ensure that lessons are not entirely translation-focused. Materials that spark heated debates or that impose one culture over another should be avoided. The content chosen should be expressed in such a way that it leaves no room for negative interpretation on the part of the student. The textbooks that teachers select moreover should contain a wealth of target-culture specific graphic content (e.g. diagrams, images, etc.), and should not be overly reading-heavy.

\section{Selecting Suitable Language Teaching Methods}

The classroom atmosphere of a cultural studies course ought to be as natural as possible. One such suitable approach is the "inductive approach" which is considered as an important component in academic achievement (Ropo 1987). In this approach, the teacher first provides examples, and then asks learners to extract meaning and find the rules to those examples (Schaffer, 1989.

The student, towards the end of this, first becomes aware of their own culture and then the target culture, and finally comes to learn how to extract their own information the culture on a cross-cultural dimension.

According to Bada (2000), "the need for cultural literacy in ELT arises mainly from the fact that most language learners, not exposed to cultural elements of the society in question, seem to encounter significant hardship in communicating meaning to native speakers" (p. 101). In order to put this into the foreground, the teacher can directly open a discussion with their students about the less appealing or unseen aspects of the target culture featured in the materials being used. The degrees of cross-cultural awareness, as well as the methods used by teachers, are both keys to cultural training being successfully carried out. For example, the teacher can elaborate the importance of the word "please" in British culture when teaching a low-level topic such as imperative sentences. The teachers' role here is as both a motivator, as well as a transmitter of culture.

Teachers should use a method of teaching that encourages students to form their own opinions, as well as that allows them to gain the ability to question what they learn. Teacher's hard-line, instruction-barking approach to teaching culture leaves a bad taste in students' mouths, and this experience will do little in the way of arousing students' sensitivity towards culture. Students will not accept teachers' attitude and approach if they try to impose the target culture upon them as being a wonderful thing, and resultingly, they will tune out.

\section{Effectiveness of Communicative Language Teaching}

Almost half a century ago, Chastian (1971) gave a talk on creating an environment that encourages students to talk: "more important than error-free speech is the creation of an atmosphere in which the students" (p. 249). CLT has got popularity in the last forty years or so, and teachers can use it effectively in their classrooms (Farooq, 2015). The teacher, thus, ought to create an environment in which their students can share and defend their ideas. Should students feel hesitant; their linguistic competency will surpass their cultural competency. Communicative language teaching is one approach that aims to have students create "meaning", and entails teachers being able to evaluate their students at a much higher level. Here, the teacher presents students with the opportunity to discover themselves rather than focusing on their grammar or on historical facts. This method, upon being applied in the classroom, will positively raise students' sense of cultural awareness and sensitivity (Byram \& Kramsch, 2008). The Common European Framework of 
Reference for Languages accommodates this method, and outlines that good language students need to possess knowledge, skills, existential competence, and the ability to learn (Council of Europe, 2003).

\section{International Educational Programmes}

Zhu (2014) claims that language teaching and learning is now often perceived as an inevitably intercultural experience in which language learners learn about other cultures and peoples. If teachers do not have students with different cultural, religious, and/or linguistics backgrounds in their classrooms, this reflects poorly both on the part of them, as well as shows that people's expectations of them are low. Teachers who have lived within another culture and/or who have participated in education programmes abroad could be of a higher profile. They will actively strive to incorporate community, cultural, and global studies into their teaching programmes. Aydin (2012) concluded that education programmes have developed participants' language skills, their Professional development, and their perceptions towards culture. Nedelcu \& Ulrich (2014) also showed positive effects of the programmes are connected to enhanced communication skills and intercultural experiences exposure.

Taylor in as early as 1969 suggested that, "those who are becoming teachers should have a chance to cross over, through their students and their personal experience, to a culture different from the one in which they have been born and raised" (Taylor, 1969, p. ix). These programmes are a fantastic means of giving the education system a sense of vision, as well as shift the mentality of those who are not readily open to change. They will make them more empathetic educators. Teachers will gain the ability to think comparatively as well as to think critically.

\section{The importance of Culture of Own Country}

Whose cultures should EFL teachers bring into the class to empower their students to improve their intercultural awareness: British, American, or Anglophone culture? According to Smith (1976), if the cultural emphasis in English as a foreign language class begins to focus too much on the Anglophone culture, then language learners want to transfer the knowledge about their own cultures into the curriculum. What about preparing textbooks in each country in order to achieve these goals? It may cause distortion, problems, and stereotypical glimpses in some of the students (Clarke and Clarke, 1990). The results of Tajeddin \& Teimournezhad (2015) showed that localised ELT textbooks were more neutral than the international ELT textbooks (p.180). Instead of such textbooks, Corbett (2003) and Pulverness (2004) put the emphasis on including materials and representations of their own culture into foreign language teaching.

One important detail is that students need a deeper wealth of information about their own culture, given that they will later transfer that knowledge upon acquiring the target culture. This, thus, will lead the way to awakening students' motivation levels, as well as open them to worlds beyond their own. At times, the student can lose interest when the teacher is explaining the value of the target culture through the target language. However, authentic cultural materials of their own culture and target culture immediately increase their motivation and invite them into the heart of the topic.

\section{Conclusion}

The participant students mentioned that their high school English teachers didn't teach them enough about culture. They had noted that the textbooks they had used largely ignored the target culture, and that their teachers, more often than not, would skip over those sections due their own foreignness towards the subject, and would instead focus merely on cold linguistic rules. Some of the teachers often supported the lessons with their own cultural resources. The teachers who are interested taught the cultures by comparing/contrasting to their own country. Some of the students claimed that they learned about cultural topics on their own.

The findings indicate that attending the cultural studies course benefits language students in a number of ways. Learners understand the nature of the relationship between language and culture in the foreign language classrooms as well. As learners combine these two things, the course heightens their sense of sociocultural understanding, as well as strengthens their sense of tolerance towards other cultures. Cultural studies lead students to become more sensitive towards other cultures and change their negative attitudes into positive ones. The students agreed that reading about the target culture in language class helps them better understand what they have read, as well as also increases their vocabulary. Some of the students mentioned that learning about the target culture is important for establishing effective communication. Learning the target culture also helps students more deeply understand their own culture. In essence, the majority of the learners agreed that the target culture should be an essential part of foreign language instruction. They feel that information about the target culture needs to be included in foreign language textbooks. Students feel 
that teachers ought to discuss the importance of learning culture, as well as how and where they can apply their knowledge. This study shows how low level, unmotivated, and culturally disinterested students were able to reach a point that was higher than hoped for. Our results also show that there is a stark similarity between students' ideas and the arguments of experts on the theoretical benefits of studying culture in the foreign language classroom.

Culture encompasses a complex whole that is gained over time, as opposed to being something that members of society are born with. It, moreover, encompasses a broad number of meanings. It takes guts for a teacher to introduce culture's coat of many colours into the classroom. One of the most difficult aspects of doing this is sidelining away from the curriculum. The largest tasks that language educators are faced include obtaining target culture-focused teaching materials, utilising these materials in order to better develop students, and accelerating the process of having students gain intercultural competence. It at times can be challenging for the teacher to make their students aware of language and the role it plays in developing international understanding. It takes patience and effort in order to convince youth of the necessity of languages, as well as to make them better aware of, and to dispel their prejudices towards other cultures.

Students ought to acquire the skill of cross-cultural communication, given the fact that English is an international language, that the ability to use English is now an essential skill, and that the world is rapidly globalising. Exchange programmes, the Internet and social media, rapid travel, and a shrinking globe now means that the chance of different cultures coming into contact with one another is increasing. They need to be aware of cultural differences in order to healthily establish communication. Rejecting these cultural differences can throw the person into unavoidable and embarrassing situations. They may also struggle in situations where a more in-depth knowledge of the target culture is necessary. Being knowledgeable about the target culture in turn teaches learners how to communicate with, to interpret the target culture they are in contact with, as well as the cultural texts and topics that they read and discuss.

Cultural topics can easily be forgotten about and missed all together while students are struggling to grasp the fundamental grammar and vocabulary of the language(s) they are learning. The curriculum should be one that is inclusive of both language and culture. Providing students with an excessively grammar-heavy education only impedes their ability to handle culture-rich resources and concepts. Teachers should be well enough equipped to teach culture. The textbooks that they choose should cover the cultural aspect of language.

A teacher's knowledge of the target language may be sound, however what is more important is how they teach that language. No one is naturally born as a teacher; however solid teaching programmes can make a good teacher out of an individual.

Personal development first starts with placing value upon both one's own as well as the target culture. Wherever English as a foreign language is taught, the teacher ought to include elements from both the target culture as well as the student's native culture as part of the curriculum. In doing so, students will become better able to conceptualise both, as well as will attempt to build a bridge between both.

Furthermore, the influence of various exchange programmes upon creating an enthusiasm towards language learning is very large. These programmes show one that being competent in a language does not just about knowing linguistic rules. Cultural studies courses increase students' desire to participate in such exchange programmes.

Should students' level of awareness and tolerance towards other cultures not mature over time, what they learn will only remain theoretical, and will otherwise be of no value. In turn, teachers, textbook authors, publishers, and curriculum planners should aim towards developing students' cultural enlightenment.

\section{References:}

Adaskou, K., Britten, D. and Fahsi, B. (1990). Design decisions on the cultural content of a secondary English course for Morocco. ELT Journal, 44 ( 1), 3-10. https://doi.org/10.1093/elt/44.1.3

Ahmad, H., \& Shah, S. (2014). EFL textbooks: Exploring the suitability of textbook contents from EFL teachers' perspective. VFAST Transactions on Education and Social Sciences, 5(1), 12-20.

Alptekin, C. (2002). Towards intercultural communicative competence in ELT. ELT Journal, 56(1), 57-64. https://doi.org/10.1093/elt/56.1.57

Alsamaani, A. (2014). Evaluating classroom assessment techniques of novice Saudi EFL teachers. Journal of Arabic and Human Sciences, 7(2), 63-81. https://doi.org/10.12816/0009602

Atay, D., Kurt, G., Çamlıbel, Z., Ersin, P., \& Kaslığlu, Ö. (2009). The role of intercultural competence in foreign language teaching. Inönü University Journal of the Faculty of Education, 10(3), 123-135. https://doi.org/10.1016/j.sbspro.2009.01.283

Aydin, S. (2012). "I am not the same after my ERASMUS": A qualitative research. The Qualitative Report, 17(Art. 55), 1-23.

Bada, E. (2000). Culture in ELT. Cukurova University Journal of Social Sciences, 6, 100-110.

Baker, W. (2012). From cultural awareness to intercultural awareness: Culture in ELT. ELT Journal, 66(1), 62-70. https://doi.org/10.1093/elt/ccr017

Barnes-Karol, G., \& Broner, M. A. (2010). Using images as spring boards to teach cultural perspectives in light of the ideals of the MLA report. Foreign Language Annals, 43(3), 422-445. https://doi.org/10.1111/j.1944-9720.2010.01091.x 
Bennett, M. (1997). How not to be a fluent fool: Understanding the cultural dimensions of language. In A. E. Fantini (Vol. ed.), \& J. C. Richards (Series ed.), New Ways in Teaching Culture. New Ways in TESOL Series II: Innovative Classroom Techniques (pp. 16-21). Alexandria, VA: TESOL.

Bhawuk, D. P. S., \& Brislin, R. (1992). The measurement of intercultural sensitivity using the concepts of individualism and collectivism. International Journal of Intercultural Relations, 16, 413-436. https://doi.org/10.1016/0147-1767(92)90031-o

Bourque, J. \& Chehy, L. (1976). Exploratory Language and Culture A Unique Program. Foreign Language Annals, 9(1). 10-16. https://doi.org/10.1111/j.1944-9720.1976.tb03179.x

Brooks, N. (1969). Teaching culture in the foreign language classroom. The Florida FL Reporter 7, 20-28 https://doi.org/10.1111/j.1944-9720.1968.tb00135.x

Brown, H. D. (2000). Principles of Language Learning and Teaching [M]. 4th ed. NY: Longman.

Byram,M. (1989). Cultural Studies in Foreign Language Education. Clevedon, England: Multilingual Matters

Byram, M. (1991). Teaching culture and language: Towards an integrated model. In D. Buttjes, \& M. Byram (Eds.), Mediating languages and cultures: Towards an intercultural theory of foreign language education (pp.17-32). Clevedon, UK: Multilingual Matters

Byram, M. (Ed.). (1994). Culture and Language Learning in Higher Education. Clevedon: Multilingual Matters Ltd.

Byram, M. (1997). Teaching and Assessing Intercultural Communicative Competence. Clevedon, U.K.: Multilingual Matters.

Byram, M. \& M. Fleming (1998). Language learning in intercultural perspective. Cambridge: Cambridge University Press.

Byram, M., Morgan, C., \& colleagues. (1994). Teaching-and-learning language-and-culture. Clevedon, England: Multilingual Matters

Byram, M., Gribkova, B., \& Starkey, H. (2002). Developing the intercultural dimension in language teaching: A practical introduction for teachers. Strasbourg, France: Council of Europe.

Byram, K., \& Kramsch, C. (2008). Why is it so difficult to teach language as culture? The German Quarterly, 81(1), $20-34$. https://doi.org/10.1111/j.1756-1183.2008.00005.x

Byrd, D. R., Hlas, A. C., Watzke, J. \& Montes Valencia, F. (2011). An examination of culture knowledge: A study of L2 teachers' and teacher educators' beliefs and practices. Foreign Language Annals, 44(1), 4-39. https://doi.org/10.1111/j.19449720.2011.01117.x

Cakir, I. (2000). Developing cultural awareness in foreign language teaching. Turkey: Kirikkale University.

Chastain, K. (1971). The development of modern language skills: Theory to practice. Chicago: Rand McNally.

Cheung, C.-K. (2001). The use of popular culture as a stimulus to motivate secondary students' English learning in Hong Kong. ELT Journal, 55, (1) 55-61. https://doi.org/10.1093/elt/55.1.55

Chlopek, Z. (2008). The intercultural approach to EFL teaching and learning. English Teaching Forum, 4, 10-27.

Choudhury, R.U. (2014). The role of culture in teaching and learning of English as a foreign Language. Express, International Journal of Multidisciplinary Research, 1, 1-20.

Clarke, J. and Clarke M. (1990). 'Stereotyping in TESOL materials', in Harrison, B. (ed.). Culture and the Language Classroom. Hong Kong: Modern English Publications and the British Council.

Cortazzi, M. \& Jin, L. (1999). Cultural mirrors: Materials and methods in the EFL classroom. In Hinkel (ed.), Culture in second language teaching and learning (pp. 196-219). Cambridge: Cambridge University Press.

Corbett, J. (2003). An intercultural approach to English language teaching. Clevedon: Multilingual Matters. https://doi.org/10.21832/9781853596858

Council of Europe. (2001). Common European Framework of Reference for Languages: Learning, teaching, assessment. Cambridge: Cambridge University Press.

Crawford-Lange, L. M., \& Lange, D. L. (1984). Doing the unthinkable in the second-language class-room: A process for the integration of language and culture. In TV. Higgs (Ed.), Teaching for proficiency, the organizing principle (pp. 139-177). American Council of Teachers of Foreign Language

Çakır, I. (2015). Instructional Materials Commonly Employed by Foreign Language Teachers at Elementary Schools. International Electronic Journal of Elementary Education, 8(1), 69-82

Damen, L. (1987). Culture learning: the fifth dimension in the language classroom. Cambridge: Cambridge University Press.

Davis, J. J. \& Markham, P. L. (1991). Student attitudes towards foreign language study at historically and predominantly black institutions. Foreign Language Annals, 24, (3), 227-236. https://doi.org/10.1111/j.1944-9720.1991.tb00467.x

Day, R.R. (1991). Models and the knowledge base of second language teacher education. University of Hawai Working Papers in ESL, 11(2), pp. 1-13.

Demircioğlu, Ş., \& Çakır, C. (2015). Intercultural competence of English language teachers in International Baccalaureate World Schools in Turkey and abroad. Journal of language and linguistic studies, 11(1), 15-32. https://doi.org/10.5539/ies.v9n9p1

Devrim, Devo Y. \& Bayyurt, Y. (2010). Students' understandings and preferences of the role and place of 'culture' in English Language Teaching: A focus in an EFL context. TESOL Journal, 2, 4-24.

Drewelow, I. (2013). Impact of instruction on shaping or reshaping stereotypical cultural representations in an introductory French course. Foreign Language Annals, 46(2), 157-174. https://doi.org/10.1111/flan.12029

Duff, P. A. (2001). Language, literacy, content, and (pop) culture: Challenges for ESL students in mainstream courses. The Canadian Modern Language Review, 58(1), 103-132. https://doi.org/10.3138/cmlr.58.1.103

Dweik, B. S., \& Al-sayyed, S.W. (2015). Attitudes of Jordanian students, teachers and educationalists towards including culture in EFL classes and textbooks “Action Pack 12". International Journal of Social Sciences, 40(1), 1126-1141.

Edgerton, M. F. (1971). A philosophy for the teacher of foreign languages. The Modern Language Journal, 55(1), 5-15. https://doi.org/10.1111/j.1540-4781.1971.tb03595.x

Eoyang, E. (2003). Teaching English as Culture: Paradigm Shifts in Postcolonial Discourse. Diogenes, 50(2): 3-16. https://doi.org/10.1177/0392192103050002001

Fishman, J.A.(1982). Sociolinguistic foundations of bilingual education. Bilingual Review / La Revista Bilingüe. 9 (1) pp. 1-35

Farooq, M. U. (2015). Creating a communicative language teaching environment for improving students' communicative competence at EFL/EAP. International Education Studies, 8(4). https://doi.org/10.5539/ies.v8n4p179

Fox, R., \& Diaz Greenberg, R. (2006). Culture, multiculturalism, and foreign/world language standards in U.S. teacher preparation programs: Toward a discourse of dissonance. European Journal of Teacher Education, 29, 401-422. https://doi.org/10.1080/02619760600795270 
Galloway, V. B. (1984). Communicating in a cultural context. ACTFL Master Lecture Series. Monterey, CA: Defense Language Institute.

Genc,, B. \& Bada, E. (2005). Culture in language learning and teaching. The Reading Matrix, 5(1), 73-84

Gorjian, B. \& Aghvami, F. (2017). The Comparative Study of EFL Teachers and Learners' Perceptions on the Importance of Teaching Culture. Applied Linguistics and Language Learning Journal, 3 (3), 71-78.

Gönen, S., \& Sağlam, S. (2012). Teaching culture in the FL classroom: Teachers' perspectives. International Journal of Global Education, 1(3).

Gözpınar,H. (2014). English Teachers' Interest in Proverbs in Language Teaching. The Journal of International Social Research, 7 (31)

Hejazi, M., Ghonsooly, B., Pishghadam, R., \& Ahmadi, H. S. (2015). Home Culture Attachment and Comprehending L2 Written Texts: A Study on EFL learners in Iran. Mediterranean Journal of Social Sciences, 6(4). https://doi.org/10.5901/mjss.2015.v6n4s3p383

Hadley, A. O. (1993). Teaching language in context. Boston: Heinle and Heinle Publishers.

Hammerly, H. (1982). Synthesis in language teaching. Blaine, WA: Second Language Publications.

Hamp-Lyons, E. (1983). Motivation for learning English as a world language: Integrative and instrumental. World Language English, 2(3), 145-149. https://doi.org/10.1111/j.1467-971x.1983.tb00541.x

Han, T. (2016). Yabanc1/ İkinci Dil Olarak Türkçe ve İngilizce Sınıflarında Kültür Öğretimi. Kastamonu Eğitim Dergisi [Culture Teaching in Turkish and English As-A-Foreign/ Second Language Classrooms]. Kastamonu Eğitim Dergisi, 24(2), 703-718.

Harrison, B. (ed.) (1990). Culture and the Language Classroom. London: Modern English Publications

Higgs, T. (Ed.). (1984). Teaching for proficiency, the organizing principle. Lincolnwood, IL: National Textbook Company.

Ho, S. T. K. (2009). Addressing culture in EFL classrooms: The challenge of shifting from a traditional to an intercultural stance. Electronic Journal of Foreign Language Teaching, 6(1), 63-76.

Hofstede, G. \& Hofstede, G. J. (2005). Cultures and Organizations: Software of the Mind (Rev. 2nd ed.). New York: McGraw-Hill.

Hol, D. \& Erarslan, A. (2015). Moving beyond Language: Awareness of EFL Learners in Target Language Culture. CBU International Conference Proceedings. https://doi.org/10.12955/cbup.v3.620

Izadpanah, S. (2011). The Review Study: The Place of Culture in English Language Teaching. US China Foreign Language, 9(2), 109-116.

Jabeen, F., \& Shah, S. K. (2011). The role of culture in ELT: learners' attitude towards the teaching of target language culture. European Journal of Social Sciences, 23(4), 592-601.

Jiang, X., \& Cohen, A. D. (2012). A critical review of research on strategies in learning Chinese as both a second and foreign language. Studies in Second Language Learning and Teaching, 1, 9-43. https://doi.org/10.14746/ssllt.2012.2.1.2

Kahraman, A. (2016). Teachers"e and learners"e attitudes towards culture and culture learning in a Turkish context. Journal of Language and Linguistic Studies, 12(2), 01-12.

Karabinar, S. \& Guler, C. Y. (2012). The attitudes of EFL teachers towards teaching culture and their classroom practices. Journal of Educational and Social Research, 2(2), 113-126.

Keller, H, H. \& Ferguson, J. W. (1976). A cultural introduction to foreign languages. Foreign Language Annals, 9(1), 50-55. https://doi.org/10.1111/j.1944-9720.1976.tb03187.x

Kitao, K. (2000). Teaching culture in foreign language instruction in the Unites States. Doshisha Studies in English, 52, 285-306.

Klayman, N.B. (1976). Teaching culture in English to motivate foreign language study. Foreign Language Annals, 9(4), $289-293$. https://doi.org/10.1111/j.1944-9720.1976.tb02651.x

Klippel, F. (1994). Cultural aspects in foreign language teaching. Journal for the Study of British Cultures, 1(1), 49-61.

Kramsch, C. (1993). Context and culture in language teaching. Oxford: Oxford University Press.

Kramsch, C. (1998). Language and Culture. Oxford: Oxford University Press.

Kramsch, C. (2001). Language and Culture. Oxford: Oxford University Press.

Krashen, S. (1982). Accounting for child-adult differences in second language rate and attainment. In S.Krashen, R. Scarcella, \& M. Long (Eds.), Child-adult differences in second language acquisition (pp. 202-226). Rowley, MA: Newbury House.

Leward, H. E. (1968). A tentative outline of problems in the knowledge understanding and teaching of cultures pertaining to the target language. The Modern Language Journal, 52(5), 301-309. https://doi.org/10.1111/j.1540-4781.1968.tb01909.x

Lunenburg, F. C., \& Ornstein, A. O. (2012). Educational administration: Concepts and practices (6th ed.). Belmont, CA: Wadsworth/ Cengage Learning.

Matsumoto, D. (2009). Teaching about culture. In: Gurung RAR, Prieto LR (Eds.), Getting Culture: Incorporating Diversity Across the Curriculum (pp.3-10). Sterling, VA: Stylus.

McKay, S. L. (2002). Teaching English as an international language. Oxford: Oxford University Press.

Minami, M., and Ovando, C. (2004). Language Issues in Multicultural Contexts. In J Banks (Ed.), Handbook of Research on Multicultural Education (pp.567-588). San Francisco: Jossey-Bass.

Morain, G. G. (1970). Cultural pluralism. In I. L. Lange (Ed.), Britannica review of foreign language education (pp. 59-95). Chicago: Encyclopedia Britannica.

National Standards in Foreign Language Education Project (2006). Standards for foreign language learning: Preparing for the 21 st century. Yonkers, NY: American Council for the Teaching of Foreign Languages

Omaggio, A. (1986). Teaching language in context: Proficiency- oriented instruction. Boston: Heinle \& Heinle.

Önalan, O. (2005). EFL teachers ${ }^{\text {ee }}$ perceptions of the place of culture in ELT: A survey study at four universities in Ankara/Turkey. The Journal of Language and Linguistic Studies, 1(2), 215-235.

Peck, D. (1998). Teaching Culture: Beyond Language. Yale: New Haven Teachers Institute.

Prodromou, L. (1988). English as cultural action. ELT Journal, 42 (2), 73-83. https://doi.org/10.1093/elt/42.2.73

Pulverness, A. (1999). The fifth skill- intercultural awareness and language learning. Anthology Issues, 6 (10), 26-30.

Pulverness, A. (2004). Here and There: Issues in Materials Development for Intercultural Learning. Retrieved May, 15, 2018 from http://www.academia.edu/268758/Here_and_There_Issues_In_Materials_Development_for_Intercultural_Learning

Rafieyan, V., Norazman Bin Abdul Majid, \& Lin, S. E. (2013). Relationship between attitude toward target language culture instruction and pragmatic comprehension development. English Language Teaching, 6(8), 125-132. https://doi.org/10.5539/elt.v6n8p125

Rivers, Wilga M. (1968). Teaching foreign-language skills. Chicago, University of Chicago Press. 
Saluveer, E. (2004). Teaching cultures in English classes. Unpublished master's thesis, University of Tartu, Estonia.

Ropo, E. (1987). Skills for Learning: A Review of Studies on Inductive Reasoning.Scandinavian Journal of Educational Research, 31(3)3, 1-39. https://doi.org/10.1080/0031383870310103

Schaffer, C. (1989). A comparison of inductive and deductive approaches to teaching foreign languages. Modern Language Journal, 73, 395-403. https://doi.org/10.1111/j.1540-4781.1989.tb05319.x

Schuetze, U. (2008). Exchanging second language messages online: Developing an intercultural communicative competence. Foreign Language Annals, 41(3), 660-673. https://doi.org/10.1111/j.1944-9720.2008.tb03323.x

Seelye, H. N. (1984). Teaching culture: Strategies for intercultural communication ( $2^{\text {nd }}$ Ed.). Lincolnwood, IL: National Textbook.

Sercu, L. (1998). In-service teacher training and the acquisition of intercultural competence. In Byram, M. \& Fleming, M. (eds.), Language learning in intercultural perspectives (pp. 255-289). Cambridge: Cambridge University Press.

Sercu, L. (2005). Foreign language teachers and the implementation of intercultural education. A comparative investigation of Belgian English, French and German teachers' professional self-concepts and teaching practices. European journal of teacher education, 28(1), 87-105. https://doi.org/10.1080/02619760500040389

Sercu,L., Gracia,M. and and Prieto, P. (2004). Culture teaching in foreign language education.EFL teachers in Spain as cultural mediators. Porta Linguarum, 1 (1), 85-102. Retrieved May, 31, 2018 from http://hdl.handle.net/10481/28351

Smith, L. (1976). English as an international auxiliary language. RELC Journal, 7(2), 38-43. https://doi.org/10.1177/003368827600700205

Stainer, F. (1971). Culture: A motivating factor in the French classroom. In C. Jay \& P. Castle (Eds.), French language education: The teaching of culture in the classroom. Springfield, IL: State Department of Public Instruction

Stapleton, P. (2000). Culture's role in TEFL: An attitude survey in Japan. Language, Culture and Curriculum, 13(3), 291-305. https://doi.org/10.1080/07908310008666605

Steiner, G. (1971). In Bluebeard's Castle: Some Notes Towards the Redefinition of Culture. New Haven, CT: Yale UP.

Stern, B.B. (1992). Historical and personal nostalgia in advertising text: the fin de sieÁcle effect. Journal of Advertising, 21 (4), 11 22. https://doi.org/10.1080/00913367.1992.10673382

Stern, H. H. (1983). Fundamental concepts of language teaching. Oxford: Oxford University Press.

Tajeddin, Zia \& Teirmournezhad, Shohreh. (2015). Exploring the Hidden Agenda in the Representation of Culture in International and Localised ELT Textbooks. The Language Learning Journal, 43 (2), 180-193. https://doi.org/10.1080/09571736.2013.869942

Taylor, H. (1969). The world as teacher. Garden City, NY: Doubleday.

Thanasoulas, D. (2001). The importance of teaching culture in the foreign language classroom. Radical pedagogy, 3(3), 1-25.

Tomalin, B. (2008). Culture the fifth language skill. Retrieved May 15, 2018 from http://www.teachingenglish.org.uk/ think/articles/culture-fifthlanguage-skill

Tsou, W. (2005). The effects of cultural instruction on foreign language learning. RELC Journal, 36(1), $39-57$. https://doi.org/10.1177/0033688205053481

Tuna, Ö. K. \& Razı, S. (2016). Integrating Culture into ELT Classes: What, Why, and How? Procedia-Social and Behavioral Sciences, 232, 41-48. https://doi.org/10.1016/j.sbspro.2016.10.009

Türkan, S., and Çelik, S. (2007). Integrating culture into EFL texts and classrooms: Suggested lesson plans. Online Submission, 1(1), $18-33$.

Valdes, J. (1990). The inevitability of teaching and learning culture in a foreign language course. In B. Harrison (Ed.), Culture and the Language Classroom (pp. 20-30). ELT Documents: 132. London: Modern English Publications.

Yeşil, S., \& Demiröz, H. (2017). An exploration of English language teachers' perceptions of culture teaching and its effects on students' motivation. International Journal of Progressive Education, 13, 79-95

Zhu, H. (2014). Exploring Intercultural Communication: Language in Action. London: Routledge. https://doi.org/10.1017/S0047404514000797

Received: May 25, 2018

Accepted: June 11, 2018 


\section{(Appendix 1)}

\section{Contributions of the Cultural Trainings}

- Reading about the target culture in language class increases vocabulary.

- Learning (about) the target culture is important for establishing effective communication.

- Having knowledge of the target culture helps me better understand what I read/have read.

- Having knowledge of the target culture helps us understand the language we're learning better.

- Cultural studies lead students to become more aware of/sensitive towards other cultures.

- Studying the target culture changes my negative attitudes and turns into positive ones.

- Learning the target culture helps me better and more deeply understand my own culture.

- I feel that information about the target culture needs to be included in foreign language textbooks.

- I feel that it is necessary that the target culture be taught as part of language classes.

- I will definitely teach my students about the target culture when I become a language teacher.

- Teachers should place as much importance upon culture as they do on the four basic skills of speaking, writing, listening, and reading.

- I possess a fair amount of knowledge about British/American/Anglophone culture.

- The study of the target culture increases my motivation to learn the language.

- I (now) use the cultural knowledge that I had acquired in high school in university.

- This course encouraged me to examine the relationship between language and culture

- I learned and used English in meaningful contexts

- One needs to have a sound understanding of the target culture in order to fully grasp its literature.

- It increases my motivation to learn the language

- It helps me overcome my communication apprehension

- I have a higher level of self-confidence in learning and using English

- I am better at speaking the language after these cultural-oriented courses

- It offers a reason to study the target language, makes the learning process real.

- I am more aware of/sensitive towards other cultures

- I better and more deeply understand my own culture

- I possess a fair amount of knowledge of the target culture.

\section{(Appendix 2)}

\section{High School Cultural Training Experience}

- I am not exposed to any form of cultural studies at high school

- The current curriculum blocks to inclusion of culture in ELT

- Teachers should make time for their professional development

- I learned about cultural topics on my own, not with the support of my high school teachers

- I don't feel that my high school English textbooks taught us enough about cultural topics

- I feel that information about the target culture needs to be included in the curriculum

- Our high school English teachers would skip the sections of our textbooks that dealt with culture.

- My high school English teachers taught me enough about British/American/Anglophone culture .

- My high school English teachers had discussed about the importance of learning (about) British/American/Anglophone culture

- My high school English teachers had often taught culture by comparing/contrasting cultures

- My high school English teachers had often supported their lessons with their own cultural resources

- I learned about cultural topics on my own, not with the support of my high school teachers

- I don't feel that my high school English textbooks taught us enough about cultural topics

- Whatever/all of what I learned about cultural topics I had learned from my high school textbooks.

- My high school English teachers had discussed about how we could apply/where we could use our knowledge about British/American/Anglophone culture.

- My high school English teachers were uninterested in/unenthusiastic about teaching culture 